\title{
Studying of functions of Imagination in the Elite Sport: the Analysis of Structural and Functional Interrelations of Images and Representations with Personal Characteristics of Professional Athletes
}

\author{
Mariia S. Sevost'ianova* \\ Siberian Clinical Center of Federal Medical \\ and Biological Agency \\ 26 Kolomenskaia Str., Krasnoiarsk, 660037, Russia
}

Received 09.12.2015, received in revised form 12.01.2016, accepted 29.03.2016

\begin{abstract}
Article presents the results of empirical research of interrelations between images and representations used by athletes in training process and during preparation for competitions with actual state and key psychological characteristics. Research approves a new author's questionnaire "The individual card of visual representations of the athlete" created as a result of systematization of experience of using different techniques of visualization by more than 240 professional athletes - members of national teams of Russia. Results of using this questionnaire show that application of this technique allows to reflect the contents and changes of a set of images and representations in active repertoire of the athlete most fully. Moreover, application of a new technique in total with the proved methods of diagnostics of psychological characteristics of athletes and methods of statistical data processing allowed us to allocate 3 complex psychological key factors of psychological readiness and successful psychological training for players of Russian national team on rugby (N=23): 1. «Management (active influence and control) of a situation»; 2. "Anticipation and the advancing overcoming»; 3. "Modeling of a situation and achievement of optimum fighting spirit".
\end{abstract}

Keywords: psychological maintenance in sport, actual psychological state, imagery use, imagery types, imagery functions, factors of psychological readiness.

DOI: 10.17516/1997-1370-2016-9-4-1023-1034.

Research area: culture studies, psychology.

\section{Introduction}

Nowadays, psychological and psychophysiological preparation is an essential and necessary element of sports training of all athletes of national teams of the Russian Federation (Samoylov, 2014).
The main practical goal of a sports psychologist is to maximize the expression of all features and potential reserves of the athlete to achieve the highest sport result and kept it for a long time.

It is authentically confirmed, that psychological preparation has to be systematic,

(C) Siberian Federal University. All rights reserved

* Corresponding author E-mail address: SevostyanovaMS@yandex.ru 
long time and individual to show effective and steel results. Because the identity of each athlete is unique and like a difficult, constantly evolving and elaborate system, so psychological methods which can be effective in the solution of problems of one athlete, can be inefficient for another, even if problems, at first sight, are formulated by athletes in similar way (nervous trembling before competition, fear to be traumatized, etc.) (Sivitsky, Melnik, Rodionov, Ulyaeva, 2014).

That's why, the psychologist, during the course of specific work with each athlete, usually makes an individual plan of psychological diagnostics, correction of dysfunctional states, psychological rehabilitation and restoration after mental overload and stress and, at last, purposeful and conscious preparation for constant and heavy trainings and important competitions. By today, there is already a list of effective and proven methods and techniques of work with athletes at different stages of their psychological support: progressive muscular relaxation, autotraining, techniques with biofeedback, cognitive technicians, technology of visualization, breathing exercises, ideomotor training (Gorskaya, Samoylov, 2014). Now it is necessary to study thoroughly in which combinations it will be better to use these techniques in the complex process of preparation of athletes from different types of sport taking into account the challenges and problems of training process at each stage of their professional career. So, the activity of the psychologist "turns into a creative, unique interaction with each particular athlete" (Sivitsky, Melnik, Rodionov, Ulyaeva, 2014).

Despite the fact that such science as sports psychology has centenary history and today it develops especially promptly, the introduction, application and adaptation of theoretical knowledge in practice continues to remain an actual problem of modern sport science.
On the one hand, the achievements of modern Russian sports psychology are represented by a large number of fundamental theoretical and focused on practice researches of processes of adaptation, a goal-setting, selfcontrol and self-development among athletes of the group of highest sports skill, which mention the most different aspects of sports psychology, such as researches of professionally important qualities of athletes from different types of sport, or the descriptions of the principles of psychological training of athletes on the eve of important competitions etc. Upon the hole, these researches describe modern strategies of effective psychological maintenance of training process of athletes in general, especially if we talk about preparation for most important competitions, such as the World Cup or Olympic Games.

On the other hand, results of specialized anonymous questioning of 204 sportsman of Russian national team (119 men, 185 women ,the category isn't lower than the candidate for the Master of Sports) showed in practice that $69,7 \%$ among men and $24,7 \%$ among women have even no approximate understanding of the purposes and advantages of interaction the athlete with the psychologist. Only $4,2 \%$ of men and $8,2 \%$ of women recognized that had experience of interaction with the psychologist throughout at least 3 meetings (including in group), and only $1,6 \%$ of men and $4,7 \%$ of women shared that for today they have the personal psychologist, and individual psychological maintenance has long system character.

But, despite all this, $17,6 \%$ of men and $41,1 \%$ of women remembered in their sports career at least one episode or even the whole period when they were in great need of professional psychological help. $60,7 \%$ from their number didn't ask for the help (among the key reasons of not address - absence of the qualified psychologists and availability of their help, 
mistrust to the psychologist as he works with whole team, so and with rivals too, feeling of awkwardness and shame before the trainer and other athletes) (Sevostyanova, 2014).

In particular this means that the athletes have to deal with their psychological problems, using their intuition, councils and experience of others or their own experience of overcoming crisis situations.

Actually, during the same special interview with high-class athletes it was identified that 187 out of 204 respondents (91.6\%) have their own unique system of «psychological preparation», built in experienced and intuitive way. The important conclusion was made - that irrespective the type of sport, age or sex athletes understand «the individual psychological preparation» as an active conscious using during the precompetitive period a set of emotionally significant verified images and representations mainly for the purpose of removal of alarm (relaxation) or, on the contrary, achievement of an optimum level of activation (excitement) frequent in combination with elements of respiratory gymnastics $(51,34 \%)$, ideomotor training $(22,4 \%)$ or auto-training $(44,3 \%)$. In other words, athletes use various representations and images in imagination and select them in their own intuitive way. This is a basic element of psychological and mental preparation for the majority of athletes. This is what athletes call "I tune in to a competition / match / run / swim". Legitimate questions arise immediately: 1) what better to imagine to be successful and productive? 2) how to imagine? 3) when on time is it better to imagine something?.

From our practical experience we can notice, what athletes especially often wonder about advantages or harm of representation themselves in the imagination like the winner, the champion, standing on a pedestal on the eve of competition. While some argue that it helps them to relieve anxiety and tune ahead of the competition, others, on the contrary, claim that it prevents them to tune in to the competition, reduces the motivation, strikes fear not to meet the expectations of the coach, relatives, etc.

For today there is no clear understanding of the impact of the specific content of the images on the current actual emotional and functional state of the athlete. It is also unclear - the athlete helps or does harm to himself imagining before starting these or those scenes and actions. All of the above suggests the high relevance and practical significance of studying the problems of using imagination in professional sports.

\section{Theoretical framework:}

to a problem of creation an alternative questionnaire for studying the individual system of images

\section{and representations \\ of professional athletes}

In recent years surge of interest to the problem of imagination in sport is obvious. But, according to some authors, none of the models do not reflect all aspects and diversity of theoretical and empirical evidence of the effectiveness of the use of imagination in the sport. These models also do not give an adequate idea of the psychological mechanisms that ensure a positive impact of mental images. Moreover, according to them "weak continuity between different generations of researches makes it difficult to develop a unified model" (Veraksa, Gorovaya, 2011).

Let's address to the existing tendencies of studying imagination in sport. Important to mention, that in sport imagery research, five types of imagery have been the focus of many recent investigations. Initially derived from the framework proposed by Paivio (1985) and later operationalized by Hall, Mack, Paivio, and Hausenblas (1998), these are cognitive specific (CS; imagery of skills), cognitive general (CG; imagery of strategies, routines, and game 
plans), motivational specific (MS; imagery of goal achievement), motivational general-arousal (MG-A; imagery of stress, anxiety, and arousal), and motivational general-mastery (MG-M; imagery of being self-confident, mentally tough, focused, and positive). Each of these types is also represented by a subscale on the Sport Imagery Questionnaire (Hall et al., 1998) (Nordin, Cumming, 2008). In particular, the Russian version of the questionnaire SIQ used in a number of researches among Russian athletes of all ages and sports for studying the functions of imagination.

But, contrary to the "what you see is what you get" notion, however, a number of recent studies have found that several types of imagery may be related to one function, and that several functions may be served by one type of imagery. To continue with the above example, CS imagery can also impact self-efficacy and MG-M imagery can also improve motor skill performance (Nordin \& Cumming, 2005a). The imagery types could serve one or more functions, but this would be dependent on the meaning applied to the image by the athlete. In a similar vein. Short et al, (2004) modified the SIQ to allow athletes to indicate not only how frequently they engage in a particular imagery type (the traditional response format for the SIQ), but also to indicate why they did so (function). $13 \%$ of the sample circled more than one function for any given SIQ item. Thus, the study indicated that individual differences exist in the imagery type-imagery function relationship, and that athletes may engage in one image for several reasons as well as engaging in several images for a singular reason. As such, these findings contest the applied model's simple rule that "what you see is what you get" and suggest that the SIQ subscales are likely best viewed as imagery types rather than functions (Nordin, Cumming, 2008). Moreover, from the practical point of view our previous researches also showed, that application of the Russianlanguage version of the questionnaire SIQ on a selection of the Russian athletes was followed by a number of objective difficulties. According to athletes, difficulties of filling SIQ were caused by insufficiency (qualitative and quantitative) of the offered options for the developed descriptions of functions of imagination in sport, and also excessive generality of concepts and lack of a clear understanding by the athlete of the semantic maintenance of the offered images (Sevostyanova, 2014). In this regard, we, using comments and additions of athletes, came to a conclusion about need of creation of an alternative questionnaire.

At the first investigation phase we collected and analyzed information about the contents, specifics and frequency of using visual images by athletes of the group of the highest sports skill in training process, during the period before competitions and directly before the start (less than 3 hours). During special interview we interrogated 243 athletes of Russian national teams (243 professional sportsmen, among them candidates for the Master of Sports (12,7\%), Masters of Sports (42,15\%), World Class Masters of Sports $(27,4 \%)$, Honored Masters of Sports $(17,64 \%))$. We learned in details the contents and features of using the imagination, asking different questions about imagery types ( the content of an image, for example, the visual image of oneself executing a skill) and functions ( the reason or purpose why an athlete images it), like the following: «what do you usually represent? how exactly do you imagine these images? in what period of sports training and how often do you use your system of images? what factors the whole process of selecting and using images depend on?» etc.

We found out that the maintenance of active repertoire of visual representations used by 
athletes is multiple-valued and isn't constant. And the typical set of images varies depending on a kind of sports, age of the beginning the professional sport career and, at the same time, not reveals the relationships with skill level of athlete (sportsmanship), age, biological sex and gender profile. Thus, the same image of agemates athletes from different types of sport - has various semantic loading. For one, helps to relax, promotes elimination of vegetative reactions of alarm and reduces the level of emotional pressure and stress. For other, on the contrary, lifts a muscular tone, forms subjective experience and feeling of "readiness and self-confidence". For the third - supports the necessary and sufficient level of motivational activity, carrying out the function of an acceptor of result of action.

We systematized numerous answers of athletes and as a result created the thorough list of possible images and representations $(60$ points with the ability to compliment and modify individual image) which can arise at athletes during training process and just before competitions. Thus, we allocated the general maintenance of the main images and representations of athletes from different national teams of Russia (track and field athletics, rugby, swimming in flippers, ju-jitsu, skeleton, bobsled, whitewater slalom, the manumission, female and Greco-Roman wrestling, biathlon, cross-country skiing, a rockclimbing, a thriathlon, a snowboard, bandy, etc.):

\section{The list of images and representations, used by athletes of a group \\ of the highest sports skills:}

1. I represent the atmosphere of competitions (the room, the hall, a field, stock, equipment)

2. I represent fans of rivals, how they shout and support my opponent

3. I represent judges and degree of refereeing justice
4. I represent the generalized image of the competitors, without allocating on a concrete figure

5. I represent the specific rival, to compete with whom, is the most disturbingly and essentially thing for me (as he warms up, looks at me a heavy look, wins, etc.)

6. I represent the fans, whose attention and support to me are especially valuable and important (as they watch competitions, worry)

7. I represent the trainer giving me the last instructions before start, I hear his voice, I see how he looks at me, touches me

8. I represent as I come for start under comments of the announcer listing my previous achievements, sports ranks

9. I represent myself, being in a prestarting zone (as if I see myself from outside), I watch the movements as I walk up and down here and there, trying to be adjusted (specify what exactly you do

10. I represent as I am psychologically adjusted on start (I start breathing definitely, I listen to music, I pray, I give installations to myself )

11. I represent as strenuously warm up physically (I warm muscles, I stretch, I jump on a place)

12. I represent as I come for start sure and strong (pass to the line of start)

13. I represent as I enter a condition of optimum combat readiness (directly that moment when there conviction "All! I am ready! I will make it!" appears )

14. I represent as in some seconds prior to start internal tension grows in me, in the form of a ball of fire (specify the image

15. I represent that competition lasts infinitely, I see myself exhausted, weakened physically 
16. I represent finishing line as if closer you come nearer to it the further it moves away ("the running-away target")

17. I represent as my muscles look from within as they are reduced or relax, filled with force

18. I represent how I breathe, lungs are filled with air, the thorax finishes and I relax

19. I represent as I feel the alarm and fear which are followed by unpleasant feelings in a breast and a stomach

20. I represent as in feet there are unpleasant feelings, feet become wadded, lead, I can't operate the movements

21. I represent as I lose control over a situation and become "paralyzed" (I can make nothing, I can't run, I can't float, fight, resist, etc.)

22. I represent myself concentrated on start and on the competition course, making in the head all new strategies of achievement the success

23. I represent as I am afraid to be traumatized or I receive during competitions, I feel a despair, disappointment

24. I represent myself controlling the body, skillfully owning and perfect the movements mentally

25. I represent the generalized picture of passing a distance (running, arrival, a heat, fight) in natural speed or accelerated

26. I represent as I pass a distance in the slowed-down look ("the slowed-down film")

27. I present myself, concentrated, most collected, adjusted, deriving pleasure from movements

28. I represent pleasant scenes from childhood, I feel thus in safety, protected, pacified and happy

29. I represent myself in a pleasant place where I've been earlier and where felt comfortable, weakened and confident (on the seashore, in the autumn wood, in a cave, on the blossoming meadow)

30. I represent as my self-confidence, physical force and moral tranquility force my rivals to be afraid and tremble with a meeting me

31. I represent as in case of loss I will change a method of trainings, tactics, strategy

32. I represent the playing music or other sounds (a rain sound, noise of the sea), I feel how these sounds and melodies spread on all body (what is this music

33. I represent certain smells (aroma of flowers, favorite food, specify the smell ), I feel how the body is sated with these smells

34. I represent a certain color palette (a rainbow, modulations of flowers as, etc. specify in a kaleidoscope color ), I feel esthetic

pleasure

35. I represent accurately formulated certain installations in the head (I see inscription in the head, for example "I am self-assured", "I firmly go towards the aim", etc.)

36. I represent myself standing on top, and the rivals behind me (pedestal top, mountain top, etc.)

37. I represent as I fall down, sink, tightened by a bog (I fly to a chasm, I break from the rock)

38. I represent myself soaring highly in the sky, as if observing from height of bird's flight all the situation

39. I represent as I carry out some separate movement, action, reception, which usually is impossible, repeatedly

40. I represent as after falling and loss people whose expectations I hadn't meet, look at me (the trainer, partners in team, friends, relatives - to specify who

41. I represent as in the course of competition I make a mistake and right there correct it 
(I imagine possible failures and alternative strategies in the head)

42. I represent as I cope with a condition of prestarting nervous trembling, excessive excitement as I control myself

43. I represent myself, being in a protective capsule which protects me from negative impacts of world around and keeps in me useful energy (protects my resources)

44. I represent as on my body there are additional bodies (wings grow, a tail, gills, etc. to specify that for what

45. I present myself like in the form of natural strong elements as if I possess the same force, energy and power (I'm a fire, an air, a wave, a wind, a hurricane, a volcano, to specify that

46. I present myself in the form of the static natural phenomenon (a lake smooth surface, the rock, a tree, etc. to specify that

47. I present myself like an animal (a panther, a tiger, a bear), birds, etc. to specify whom

48. I present myself in the form of an inanimate object capable to move (I am the rocket, an arrow, the plane, etc. to specify that

49. I represent as the body doesn't obey me, hands/feet make in itself the unnecessary ridiculous movements, as if I'm a wadded doll, a puppet

50. I represent as I come back home like the winner, I rejoice in the bosom of the family and close friends my victory, relatives are proud of me, feel delight

51. I represent as I talk with the person, important for me, who doesn't exist in reality, but whose opinion is especially important for me (with God, with the deceased relative, a fictional film character, etc.)
52. I represent as I make a mistake at competitions and I lose courage, I don't cope with excitement (withdraw or was withdrawn from the race etc.)

53. I represent as I carry out any action, an element ideally, better than ever

54. I represent as after a victory I have a feeling of exinanition, fatigue. I am puzzled, because the victory has not brought me pleasure as it was earlier

55. I represent as in case of failure, I finish career, leave elite sport

56. I represent myself in the center of the bright, magic, unreal, invented world with unreal plants, animals, devices, I test thus bright emotions, excitement

57. I represent the body as the car, the robot (accurately debugged design), with ideally working, powerful mechanisms and using them I can control and management the effort of will

58. I represent as completely I control a situation of competitions, feeling sure, collected

59. I represent as after a victory I give interview to journalists as I am overflowed by feeling of pleasure and pride

60. I represent as, many years later, I show my medals and awards to the children, grandsons

\section{Materials and methods}

126 athletes took part in further research. Among them athletes (men and women) of Russian national teams on underwater swimming, a rock-climbing, free-style and female wrestling, Greco-Roman wrestling, bobsled and skeleton, a snowboard, rugby and bandy. As it was told above the active set of images varies depending on sports type. Within this article we analyzed the influence of specific images on a condition of athletes - professional rugby players $(\mathrm{N}=23)$. Among them 8 athletes are the World class Masters of Sports, the others have category isn't 
lower than the candidate for the Master of Sports. The average age of sportsman was $25,4 \pm 3,23$ years, duration of professional experience in rugby $-12,9 \pm 4,22$ years, age of the beginning of professional sports career $-12,5 \pm 2,84$ years old.

To understand how different images and representations influence on a condition of athletes we invited professional rugby players to estimate how often they had been using each of 60 images during the last 3 months. We suggested to estimate a frequency of use with a classical 100th ball scale, where 0 points means "never", 50 points - "sometimes", 100 points - "constantly or always".

For assessment of an actual psychological state (dominating mood), style of self-control of activity and features of motivation we used the following methods: 1) Test of V. Gerbachevsky «Level of Claims of the Personality» for measurement the level of claims of the personality by means of diagnostics components of motivational structure; 2) L. Kulikov's test “A method of definition of the dominating mood" to determine the characteristics of the dominant personal mental state by subjective evaluations of the respondents; 3) «A questionnaire of self-organization of activity» developed by $\mathrm{E}$. Mandrikova for studying an abilities to structure personal time, to tactical planning and a strategic goal-setting.

By means of Gerbachevsky's test we estimated the expressiveness of $\mathbf{1 5}$ components of elaborate motivational structure of athletes (professional rugby players):

1) 6 components of a kernel of motivational structure: 1) internal motive; 2) informative motive; 3) motive of avoiding; 4) competitive motive; 5) motive of changing the current activity; 6) motive of self-esteem;

2) 5 components of achievement of the difficult purposes: 7) giving the personal importance to results of activity; 8) level of complexity of a task; 9) manifestation of strongwilled effort; 10) assessment of level of the reached results; 11) assessment of the potential;

3) 2 components of projections: 12) the planned level of mobilization efforts; 13) the expected level of results of activity;

4) 2 causal factors: 14) regularity of results; 15) initiative.

The questionnaire of self-organization of activity allows to obtain data on the following parameters: 1) balanced development; 2) sense of purpose; 3) perseverance, persistence; 4) fixing on the structuring activities; 5) self-organization by external tools; 6) orientation to the present.

At last, considering possibilities of our methodical opportunities (Kulikov's questionnaire), we made a complex assessment of the dominating state of rugby players on the following polar subscales:

I. the active relation to a life situation the passive relation to a life situation

II. cheerfulness - despondency

III. high vitality - low vitality

IV. relaxedness - intensity

V. tranquility - alarm

VI. stability of an emotional backgroundinstability of an emotional background

VII. satisfaction with life in general dissatisfaction with life in general

VIII. a positive image of itself - a negative image of itself

\section{Discussion}

\section{and the results of current research}

At the following investigation phase, data were processed by the method of the correlation analysis with application of coefficient of Spearmen ranks correlation. As the research has accurate practical orientation, in this study it was important not to define a set of images which disturbs, for example, the achievement of an optimum fighting state. But to identify the range 
of patterns and images in which psychologist must be focused on during complex work with rugby players, especially in the context of application different techniques of visualization, relaxation and ideomotor training. Of course, we revealed images which application increases alarm or strengthens motive of avoiding at rugby players, etc. But these data had rather informative character. In our opinion, in respect of the help to the athletes, psychological correction (intervention) with emphasis on elimination of negative images is less effective, than the psychological assistance directed on activation of adaptive successful patterns. For most of athletes the system of images which is available for them provides feeling of control over a situation and self-checking. So, we suppose it would be incorrect to "forbid" them to imagine personally significant images.

Anyway we found out that only 9 images from 60 were connected with favorable dominating mood with positive correlations ( $\mathrm{p} \leq$ $0,05)$ (Table 1).

After the correlation analysis allowed us to detail the images which influence positive on actual psychological condition and mood of athletes, we continued statistical data processing with application of the factorial analysis for further structural classification taking into account interrelations of the revealed significant images (9 images) with indicators of selforganization and components of motivational structure of athletes. As a result of factorization, three factors uniting the most part of variability of all variables were allocated (the weight of a variable is specified in brackets, at the description of factors we considered variables with factorial loading more than 0,4$)$ :

The first factor - it was called «Management (active influence and control) of a situation» is represented by the following variables:

- images No. $14(0,70), 22(0,73), 58(0,58)$ generally, it is possible to define that these images are connected with representation of internal energy, concentration, drawing up new strategies of achievement the success, a sense of confidence and control over the situation;

- the active relation to a life situation $(0,93)$ that means the expressed active optimistic relation to vital events, belief in the forces, sense of strength and readness to overcome obstacles to achieve the objectives;

Table 1

\begin{tabular}{|l|c|c|c|c|c|c|c|c|c|}
\hline & $\begin{array}{c}\text { Image } \\
12\end{array}$ & $\begin{array}{c}\text { Image } \\
14\end{array}$ & $\begin{array}{c}\text { Image } \\
17\end{array}$ & $\begin{array}{c}\text { Image } \\
20\end{array}$ & $\begin{array}{c}\text { Image } \\
21\end{array}$ & $\begin{array}{c}\text { Image } \\
22\end{array}$ & $\begin{array}{c}\text { Image } \\
25\end{array}$ & $\begin{array}{c}\text { Image } \\
32\end{array}$ & $\begin{array}{c}\text { Image } \\
58\end{array}$ \\
\hline $\begin{array}{l}\text { The active relation } \\
\text { to a life situation }\end{array}$ & - & $\mathrm{k}=0,817$ & - & $\mathrm{k}=0,687$ & - & $\mathrm{k}=0,845$ & - & - & $\mathrm{k}=0,584$ \\
\hline Cheerfulness & - & - & $\mathrm{k}=0,715$ & - & - & - & - & $\mathrm{k}=0,735$ & - \\
\hline High vitality & $\mathrm{k}=0,679$ & - & $\mathrm{k}=0,872$ & & & & $\mathrm{k}=0,726$ & $\mathrm{k}=0,666$ & - \\
\hline Relaxedness & - & - & - & $\mathrm{k}=0,547$ & $\mathrm{k}=0,754$ & - & - & - & - \\
\hline Tranquility & $\mathrm{k}=0,892$ & - & - & - & - & - & $\mathrm{k}=0,789$ & $\mathrm{k}=0,697$ & - \\
\hline $\begin{array}{l}\text { Stability of } \\
\text { an emotional } \\
\text { background }\end{array}$ & $\mathrm{k}=0,645$ & - & $\mathrm{k}=0,912$ & - & - & - & - & - & - \\
\hline $\begin{array}{l}\text { Satisfaction with } \\
\text { life in general }\end{array}$ & $\mathrm{k}=0,693$ & - & $\mathrm{k}=0,876$ & - & - & - & - & - & - \\
\hline
\end{tabular}


- perseverance and persistence $(0,58)$, assuming an application of strong-willed efforts for completion the already begun affairs and streamlining of activity;

- self-organization by external tools $(0,48)$, assuming the tendency to use external tools for activity ordering such as diaries of introspection, etc.;

- the planned level of mobilization efforts $(0,41)$, characterized by strong desire to show everything what human is capable on, to give all his best, make all possible and even more for achievement the purpose;

- regularity of results $(0,51)$ which is followed by resistant conviction that the best results aren't casual, that efforts directly influence on the result.

The second factor we conditionally called «Anticipation and the advancing overcoming», in a broader sense, it is the ability to imaginative anticipation of negative blocking states for activation of cognitive, behavioral and personal emotional and strong-willed resources for their overcoming in consciousness, like playing possible negative situations in advance and modeling multiple strategy in the mind how to overcome them. Components of this factor are:

- images No. $20(0,78), 21(0,64)$ - in general these images reflect representation of unpleasant holding-down feelings in feet up to paralysis, lack of opportunity to operate the movements, feeling that a body can make nothing;

- relaxedness $(0,58)$ - state at which the person doesn't perceive the developed circumstances as an appeal to actions or urgent changes in himself, the behavior or a situation. As he is sure, for today his main problems have been already solved successfully;
- sense of purpose $(0,81)$, measuring the feeling and understanding of the purpose and ability to concentrate on it;

- manifestation of strong-willed effort $(0,78)$ that means to work at a limit of the forces, to be diligent;

- motive of self-esteem $(0,54)$ - constant desire to surpass result, aspiration to set more and more difficult purposes, increase of desire to achieve the objectives in process of complication the purposes;

- assessment of the potential $(0,83)$ feeling of inflow of forces - that you can overcome any difficulties on the way to the purpose, feeling that it depends only on you will you overcome difficulties or not;

- motive of avoiding $(-0,46)$ - belief that the situation can cause troubles, excessive alarm about the result, constant aspiration and additional actions to avoid failures.

At last, one more factor we called "Modeling of a situation and achievement the optimum fighting spirit". This factor consists of the following components:

- images No. $12(0,76), 17(0,57), 25$ $(0,49), 32(0,89)$ - in general, this group of representations concerns feelings in a body and muscles (in particular feeling of sounds and music in a body, as this music spreads on a body, filling muscles with force) and images in which the athlete approaches the line of start (in details) surely and pass all the distance (this image athletes usually imagine in accelerated way);

- high vitality $(0,61)$ - high probability of activity and sthenicresponse todifficulties, feeling of internal concentration, a stock of forces, energy, the increased readiness for long work; 
- stability of an emotional background $(0,64)$ - predominance of positive emotional smooth, high emotional stability, so even in a state of arousal and stress the adequacy and effectiveness of mental self is maintained;

- balanced development $(0,72)$ - the subject's involvement into daily tactical planning according to certain principles;

- competitive motive $(0,83)$ - passionate desire to surpass rivals in result, to show the best result.

\section{Conclusion}

Byresultsofthisresearchkeymulticomponent factors of optimization the functional condition of professional rugby players for achievement the maximum sports result were defined. They are: 1) management (active influence and control) of a situation; 2) anticipation and the advancing overcoming, 3) modeling of a situation and achievement the optimum fighting spirit. Moreover, the complex analysis of results of the correlation and factorial analysis allows to make some conclusions:

1. The active repertoire of images and representations of rugby players is in close interrelation with some components of an actual emotional state, structure of motivation and style of self-organization of activity.

2. From all variety of the images used by rugby players only 9 have positive influence on the current psychological emotional state of athletes. In our opinion application of these images in the course of psychological maintenance of athletes during trainings and before competitions has a special therapeutic importance. It is important to consider the contents and specifics of influence of these images on actual state of athletes, and also to put the revealed tendencies into practice, supplementing technologies of mental training, ideomotor training, techniques of visualization and relaxation with these special images to reach an optimum of a sports state.

3. The new technique «The individual card of visual representations of the athlete» showed a high practicality of application (interest of athletes, clearness and concreteness of images, speed of filling, convenience). It allows not only to give a quality and quantitative standard to actual images of the specific athlete, but also serves as an instrument for introspection and self-description. Also it can be used in individual work of the psychologist with the athlete, and also for future researches of functions of imagination in an elite sport

\section{References}

Veraksa, A.N., Gorovaya, A.E. Models of using images in sports psychology. Psychological Science and Education. Electronic Journal, 2011,No.1, available at: www.psyedu.ru

Veraksa, A.N., Gorovaya, A.E. Specifics of image use among athletes specializing in track and field and rhythmic gymnastics. Psychological Science and Education, In Electronic Journal, 2011, 3, available at: www.psyedu.ru

Gorskaya, G.B. Samoylov, A.S. (2014). Strategy of psychological maintenance of training of Olympians athletes : foreign experience, In Sports psychologist. A special application, 11-17.

Nordin, S.V., Cumming J. (2008). Types and functions of athletes' imagery: testing predictions from the applied model of imagery use by examining effectiveness, In International Journal of Sport and Exercise Psychology, 6, 2, 189-206.

Samoylov, A.S. (2014). The Results of the work of the Center of physiotherapy exercises and sports medicine of Federal Medical Biological Agency of Russia within medico-psychological 
(psychophysiological) providing the athletes of national teams of the country, In Sports psychologist. A special application, 5-10.

Sevostyanova, M.S. Psychological training in sports: to a question of using techniques of visualization, Meditsinskoe obespechenie sporta vysshikh dostizhenii: Sbornik hauchnykh materialov konferentsii (First Scientific Conference Medical Support of an Elite Sport: Proceedings of scientific materials of conference), Moscow, 2014, p. 188-191.

Sivitsky, V.G., Melnik, E.V., Rodionov, V.A., Ulyaeva, L.G. (2014). Features of training of the sports psychologist taking into account specifics of professional activity, In Sports psychologist. A special application, 18-24.

\title{
Изучение функций воображения \\ в спорте высших достижений: \\ анализ структурно-функциональных взаимосвязей \\ образов и представлений с личностными характеристиками \\ профессиональных спортсменов
}

\author{
М.С. Севостьянова \\ Сибирский клинический центр \\ Федерального медико-биологического агентства \\ Центр современных психологических технологий \\ Россия, 660037, Красноярск, ул. Коломенская, 26
}

\begin{abstract}
Статья обобщает результаты эмпирического исследования взаимосвязи визуальньх образов, применяемых спортсменами сборных команд России в тренировочном и предсоревновательном периоде, с характеристиками актуального психоэмоционального статуса, структурой самоорганизации деятельности, компонентами мотивационной структурь и уровнем притязаний личности. Представленный в статье новый опросник «Индивидуальная карта визуальных представлений спортсмена», разработанный по итогам анализа опыта обращения к образам в разные отрезки спортивного ичкла более чем 240 спортсменов сборных команд России и позволяющий давать развернутую оценку содержательным и динамическим аспектам применения визуализации профессиональными спортсменами, обнаружил более высокую практичность использования по сравнению с опросником SIQ, предоставляя возможность решать разноплановье задачи диагностики и психологического консультирования спортсменов группы выстего спортивного мастерства. По итогам проведенного с применением данной методики исследования были выделены ключевые условные факторы психологической готовности к соревнованиям и достижения оптимума функционирования у членов сборной команды России по регби (N=23): 1) «Управление (активное влияние и контроль) ситуацией»; 2) «Антиципаџия и опережающее регулирование»; 3) «Моделирование ситуации и вхождение 8 оптимальное боевое состояние».
\end{abstract}

Ключевые слова: психологическое сопровождение в спорте, актуальное психологическое состояние, использование воображения, типь образов и представлений, функции образов и представлений, факторы психологической подготовленности.

Научная специальность: 24.00.00 - культурология, 19.00.00-nсихологические науки. 